\title{
"PODEMOS TIRAR, SE ACHAR MELHOR": A RELAÇÃO ENTRE NOTÍCIA E PÚBLICO NO JORNALISMO ONLINE BRASILEIRO
}

\author{
ANA MARIA ACKER \\ UNIVERSIDADE FEDERAL DO RIO GRANDE DO SUL \\ PORTO ALEGRE, RIO GRANDE DO SUL, BRASIL \\ ANA_ACKER@YAHOO.COM.BR \\ LUCAS DEMEDA DOS SANTOS \\ UNIVERSIDADE DE CAXIAS DO SUL \\ CAXIAS DO SUL, RIO GRANDE DO SUL, BRASIL \\ LUCASDEMEDA@GMAIL.COM
}

HTTP://DX.DOI.ORG/10.5902/2316882X20569 


\section{"PODEMOS TIRAR, SE ACHAR MELHOR": A RELAÇÃO ENTRE NO- TÍCIA E PÚBLICO NO JORNALISMO ONLINE BRASILEIRO}

Resumo: Este artigo busca avaliar até que ponto a internet modifica a relação entre os grandes veículos de comunicação e seu público. Para isso, se parte de uma analise descritiva de caso com base em Wolton (2003 e 2010) e bibliografia selecionada. Os resultados apontam que a internet não é preponderante na modificação nas relações comunicacionais estabelecidas, mas reforça a autonomia do receptor diante dos meios de massa. Palavras-chave: Internet; Jornalismo online; Dominique Wolton; Redes sociais; Meios de comunicação de massa

\section{"PODEMOS SACARLO, SI PREFIERES": LA RELACIÓN ENTRE NOTI- CIA Y PÚBLICO EN EL PERIODISMO EN LÍNEA BRASILEÑO}

Resumen: Ese ensayo busca evaluar hasta qué punto el internet modifica la relación entre los grandes vehículos de comunicación y su público. Para eso, partiese de un análisis descriptiva de caso con base en Wolton (2003 y 2010) y bibliografía seleccionada. Los resultados indican que el internet no es preponderante en la modificación de las relaciones comunicacionales establecidas, pero refuerza la autonomía del receptor ante los medios masivos.

Palabras-Ilave: Internet; Periodismo en línea; Dominique Wolton; Redes sociales; Medios de comunicación de masas

\section{"WE CAN TAKE IT OUT, IF YOU PREFER": THE RELATION BETWE- EN NEWS AND PUBLIC IN BRAZILIAN ONLINE JOURNALISM}

Abstract: This article seeks to evaluate to witch extent the internet changes the relationship between the mass media press and their audience. To achieve this, it begins with a descriptive case analysis based on Wolton (2003 and 2010) and selected bibliography. The results imply that the internet is not relevant to the changes in the process of the established communicational relations, but it strengthens the autonomy of the receptor.

Keywords: Internet; Online journalism; Dominique Wolton; Social media; mass media 


\section{INTRODUÇÃO}

Talvez nenhuma situação tenha deixado tão explícitas algumas caraterísticas normalmente ocultas do jornalismo brasileiro quanto a que veio a ser chamada de "Podemos tirar, se achar melhor". No dia 23 de março de 2015, a agência britânica Reuters publicou na versão brasileira de seu site uma reportagem baseada em entrevista com o ex-presidente do Brasil, Fernando Henrique Cardoso (FHC), de autoria do jornalista estadunidense Brian Winter (Figura 1). Na matéria, que aborda o escândalo de corrupção na empresa Petrobras, FHC diz que o também ex-presidente Luís Inácio Lula da Silva (Lula) "tem mais responsabilidade política" pelo caso do que a presidente Dilma Rousseff'.

No trecho seguinte, o texto aponta que, conforme um dos suspeitos de participação no crime investigado pela Polícia Federal, "o esquema de pagamento de propinas na Petrobras começou em 1997, durante o governo tucano", administração chefiada pelo entrevistado. A seguir, entre parênteses, lia-se a frase "Podemos tirar, se achar melhor"'. O teor do trecho sugere um comunicado interno entre o repórter da matéria e seu editor, aconselhando a supressão da declaração que transfere parte da responsabilidade a $\mathrm{FHC}$ e indiretamente contradiz o entrevistado. Mais tarde, a Reuters se desculpou em sua conta no Twitter, apontando que se tratava de uma "pergunta de um dos editores [...] ao jornalista que escreveu a versão original da matéria [...] publicada acidentalmente"3.

Antes da retratação, porém, o erro foi republicado involuntariamente com a reportagem na íntegra em diversos sites de notícias, como a página do jornal O Globo (Figura 2), o portal R7 (Figura 3), do conglomerado Record, o portal Terra, o site do canal RedeTV e o Jornal Metro ${ }^{4}$, além de

1 A reportagem está disponível em <http://br.reuters.com/article/domesticNews/ idBRKBNoMJ2B120150323>. A referência completa se encontra ao final do texto.

2 Embora já apagado pela agência, capturas de tela feitas por usuários e publicadas por outros portais mantém a versão com a frase original. Exemplo em <http://goo. $\mathrm{gl} / \mathrm{YtND} 4 \mathrm{l}$.

3 Comunicado completo disponível em <http://goo.gl/KNocNA $>$.

$4 \quad$ Eventualmente, os portais corrigiram o erro, mas o Google ainda preserva na versão em cachê do dia 23 de março algumas publicações originais com a frase, como é o caso do jornal A Cidade, de Ribeirão Preto. Disponível em <http://goo.gl/j27dyc>.

Rev.Cad.Comun. Santa Maria, v.21, n.2, art 1, p.15 de 31, maio/ago.2017 
CADERNOS DE COMUNICAÇÃO

UNIVERSIDADE FEDERAL DE SANTA MARIA

outros veículos menores 5 .

\title{
ENTREVISTA-FHC diz que Lula tem mais responsabilidade política em caso Petrobras do que Dilma \\ segunda-teira, 23 de norço de 2015 18:08 BR
}

\author{
Ainprini | a Uma pógina \\ $[-]$ Texto $[+]$ \\ Por Brian Winter \\ SÃo PAULO (Reuters) - A responsabilidade politica pelo escândalo de \\ corrupção na Petrobras recai mais sobre o ex-presidente Luiz Inácio Lula \\ da Silva do que sobre a presidente Dilma Rousseff, avaliou o ex- \\ presidente Fernando Henrique Cardoso, acrescentando que as indicaçöes \\ de diretores da estatal feitas por partidos nåo eram um segredo para \\ ninguém. \\ O ex-presidente tucano afirmou que Dilma provavelmente merece receber \\ menos culpa pelo escăndalo de cornupçăo na Petrobras do que seu \\ antecessor e padrinho politico. \\ "Lula está calado", afirmou Fernando Henrique em entrevista à Reuters. \\ Lula governou o Brasil entre 2003 e 2010 --periodo em que, segundo \\ os procuradores, o esquema foi mais intenso. o ex-presidente pode estar \\ planejando uma volta ao poder nas eleiçóes presidenciais de 2018. \\ "Se alguém tem mais responsabilidade politica por isso (caso Petrobras), \\ é ele, nfo ela", disse Fernando Henrique, lembrando que os ex-executivos \\ da Petrobras agora acusadas foram nomeaçóes políticas feitas durante o \\ governo Lula. \\ Entretanto, um dos delatores de esquema, 0 ex-gerente de serviços da \\ Petrobras Pedro Barusco, disse que o esquema de pagamento de propinas \\ na Petrobras começou em 1997, durante o governo tucano. \\ tirar, se achar \\ Apesar das turbulências politicas e dos protestos das ruas pedindo a \\ saida da petista do cargo, o PSOB, principal partido de oposiçắo a Dilma, \\ năo tem interesse no impeachment da presidente, segundo 0 ex- \\ presidente tucano. \\ FHC, que aos 83 anos ainda e um lider influente no PSDB, disse que a \\ deposição de Dilma pouco depois de sua reeleição, em outubro de 2014 \\ seria um processo destrutivo para a democracia brasileira, retomada \\ somente há 30 anos, principalmente porque o Ministério Público ainda năo \\ encontrou nenhuma evidência de que ela tenha participado do esquema \\ de corrupçẵo na Petrobras. Continuaçăo.. \\ aver artigo em uma página Pagina Anterior $\mathbf{1}|2| 3$ Próxima Pagina "* Pagina
}

Figura 1 - Reuters

Fonte: Captura de tela do site brasileiro da Reuters (24 mar. 2015).

O deslize da Reuters e de seus seguidores ganhou evidência na tarde do dia 24 de março, um dia após a publicação original, quando a matéria começou a ser compartilhada por usuários do Twitter e se tornou o assunto mais comentado da rede social por várias horas (Figura 4), até atingir o Facebook e virar notícia em outros portais, que, com mais ou menos ênfase, aproveitaram para criticar a situação ${ }^{6}$.

5 O termo "veículo de comunicação", aqui, sempre será usado para referir se referir a algum jornal, canal ou portal, enquanto "meio de comunicação" fará referência ao instrumento comunicacional, como sinônimo de "mídia".

6 Exemplo disponível em <http://goo.gl/C5yxJz>.

Rev.Cad.Comun. Santa Maria, v.21, n.2, art 1, p.16 de 31, maio/ago.2017 


\section{O GLOBO $\equiv$

\section{Por Brian Winter}

SÃO PAULO (Reuters) - A responsabilidade política pelo escândalo de corrupção na Petrobras recai mais sobre o ex-presidente Luiz Inácio Lula da Silva do que sobre a presidente Dilma Rousseff, avaliou o ex-presidente Fernando Henrique Cardoso, acrescentando que as indicações de diretores da estatal feitas por partidos não eram um segredo para ninguém.

O ex-presidente tucano afirmou que Dilma provavelmente merece receber menos culpa pelo escândalo de corrupção na Petrobras do que seu antecessor e padrinho político. "Lula está calado", afirmou Fernando Henrique em entrevista à Reuters. Lula governou o Brasil entre 2003 e 2010 --período em que, segundo os procuradores, o esquema foi mais intenso, $O$ ex-presidente pode estar planejando uma volta ao poder nas eleiçōes presidenciais de 2018.

"Se alguém tem mais responsabilidade politica por isso (caso Petrobras), é ele, nāo ela", disse Fernando Henrique, lembrando que os ex-executivos da Petrobras agora acusadas foram nomeaçōes políticas feitas durante o governo Lula.

Entretanto, um dos delatores de esquema, o ex-gerente de serviços da Petrobras Pedro Barusco, disse que o esquema de pagamento de propinas na Petrobras começou em 1997, durante o governo tucano. (Podemos tirar, se achar melhor) Apesar das turbulências políticas e dos protestos das ruas pedindo a saída da petista do cargo, o PSDB, principal partido de oposição a Dilma, não tem interesse no impeachment da presidente, segundo o ex-presidente tucano.

FHC, que aos 83 anos ainda 6 um lider influente no PSDB, disse que a deposição de Dilma pouco depois de sua reeleição, em outubro de 2014, seria um processo destrutivo para a democracia brasileira, retomada somente há 30 anos, principalmente porque o Ministério Público ainda não encontrou nenhuma evidéncia de que ela tenha participado do esquema de corrupçāo na Petrobras.

"Ninguém pode querer impeachment, é um problema complicado", disse o expresidente, que governou o Brasil entre 1995 e 2002.

Figura 2 - O Globo

Fonte: Captura de tela do site d'O Globo (24 mar. 2015).

Dificilmente um exemplo fabricado especialmente como ferramenta de estudo conseguiria ser tão completo e adequado à análise. No caso apresentado há de tudo: exposição de princípios utilizados na construção da notícia, "facilidades" do jornalismo online expostas na sua faceta menos apresentável e a reação maciça do público frente ao que considerou uma falha no ato de informar. O campo é rico demais para ser ignorado. É por isso - e para deixar tal caso registrado no meio acadêmico - que o presente artigo se propõe a esmiuçar o deslize da Reuters e suas variadas consequências. 


\section{ENTREVISTA-FHC diz que Lula tem mais responsabilidade política em caso Petrobras do que Dilma}

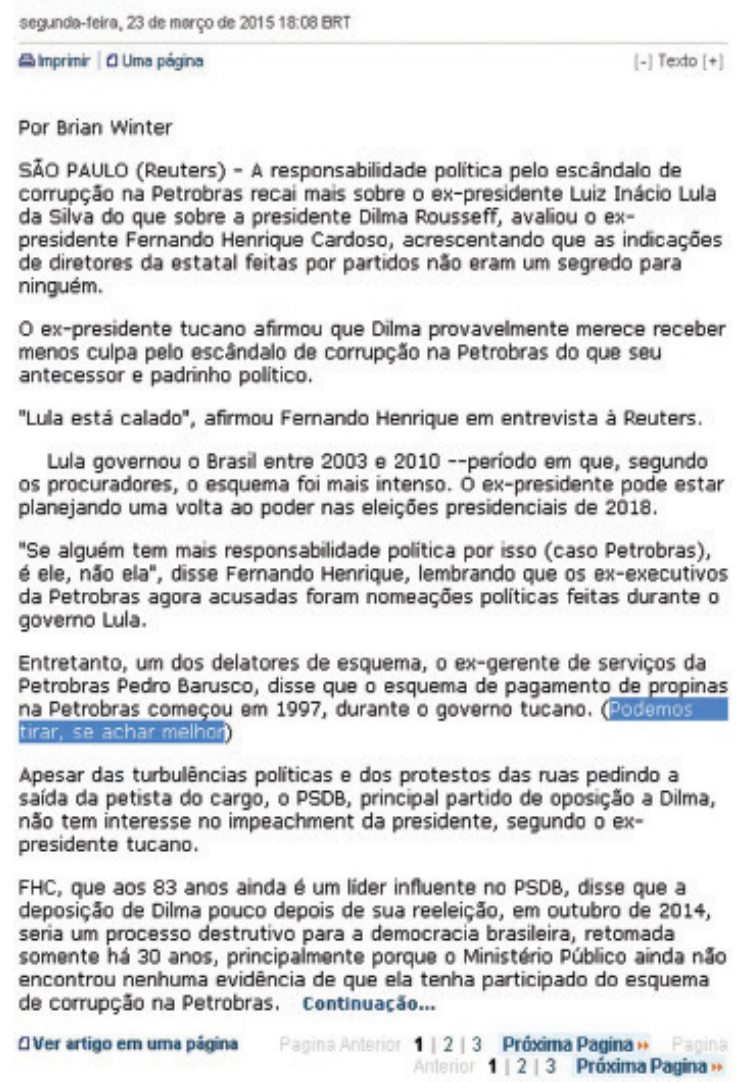

Figura $3-\mathrm{R} 7$

Fonte: Captura de tela do site R7 (24 mar. 2015).

Para isso, parte-se da tese central do sociólogo Dominique Wolton (2010). O pensador francês defende que o avanço da técnica por si só não determina avanços na comunicação. Tal ocorre somente com mudanças sociais e culturais paralelas nas relações entre os indivíduos. No entanto, o tempo da evolução "humana" quase nunca coincide com o da evolução tecnológica, o que faz com que os problemas inerentes à comunicação persistam diante do aumento da velocidade e eficácia de transmissão de informação. 


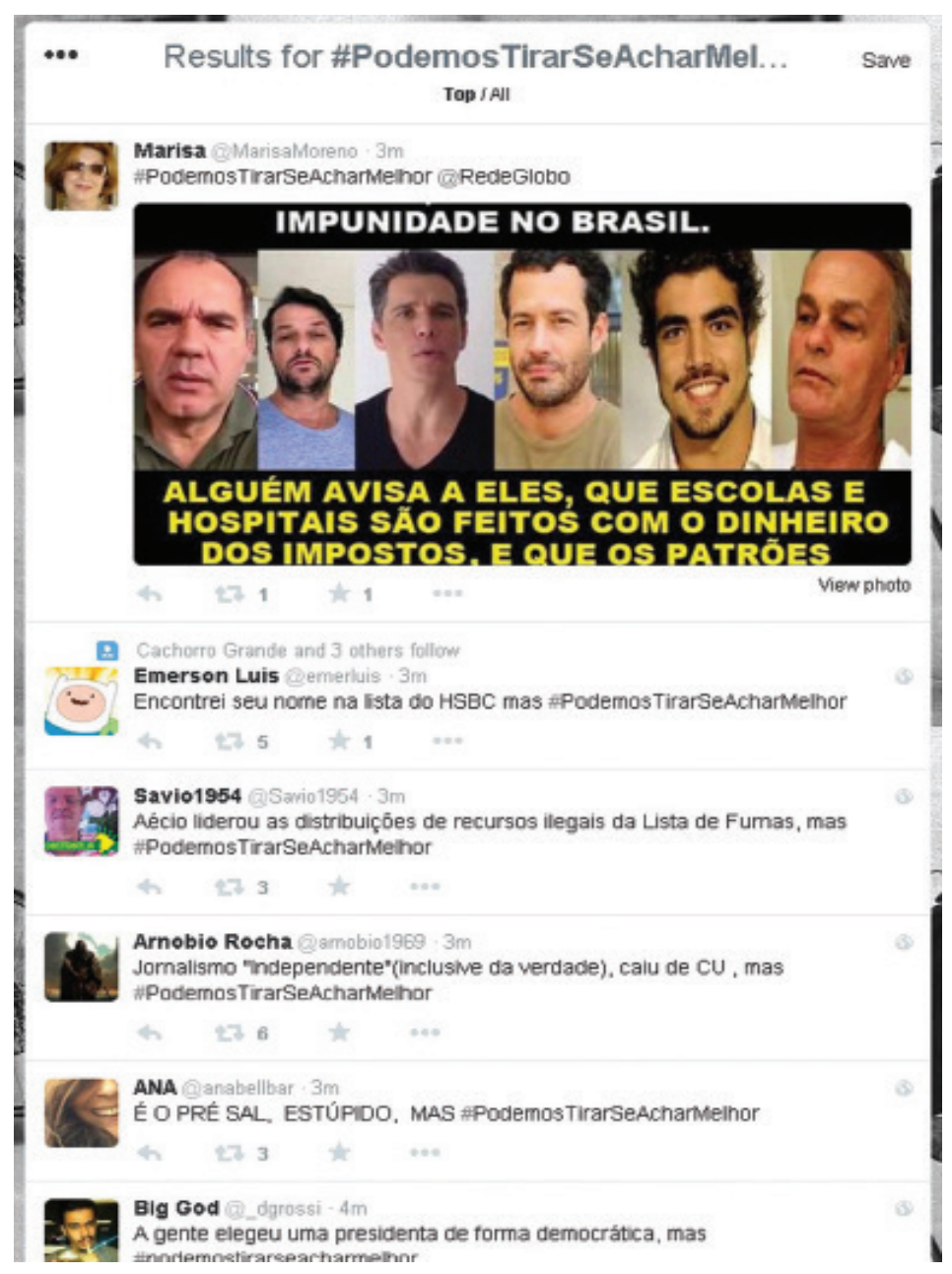

Figura 4 - Twitter

Fonte: Captura de tela da rede social Twitter (24 mar. 2015).

A "ideologia tecnicista" que, para Wolton, domina o estudo da comunicação, impede uma real reflexão sobre o processo, já que esta necessita estar ligada a uma teoria de sociedade. Entre os caminhos para quebrar essa distorção, ele aponta a necessidade de uma contextualização comparativa das novas mídias como forma de acabar com o "deslumbramento" que provocam.

Contextualizar consiste em primeiro lugar colocar as novas tecnologias na história da comunicação, compreender as razões de sua emergência, seus pontos fortes e fracos e compará-las com as mídias de massa, em resumo, inscrevê-las em uma história, ao invés de apresentá-las como um sistema técnico incomparável. É mostrar o quanto e em que são complementares, concorrentes à escrita, ao rádio e à televisão. Em outros termos, relativizar a ideia segundo a qual elas iniciariam uma página na história totalmente virgem. (WOLTON, 2003, p.140).

Rev.Cad.Comun. Santa Maria, v.21, n.2, art 1, p.19 de 31, maio/ago.2017 
Ao trazer o pensamento de Wolton para o caso da Reuters, busca-se iniciar tal contextualização para descobrir se houve efetivamente influência do meio no vazamento da frase e seus desdobramentos. Teria ele ocorrido em outras mídias? Teria sido republicado por outros veículos num meio tradicional de massa? E, principalmente, a reação do público teria impacto comparável? Inicia-se, assim, a tentativa de descobrir se a internet traz algo de novo para o processo comunicacional baseado em emissor de massa - mensagem - receptor "passivo"7.

\section{A CONSTRUÇÃO DA NOTÍCIA}

Primeiramente, contudo, é necessário voltar um pouco e explicar o que diferencia a frase publicada de forma acidental pela Reuters de um mero deslize aleatório. Afinal, não faltam exemplos de erros motivados pela dinâmica do jornalismo diário que vieram a público: vez ou outra um periódico impresso sai sem uma legenda ou linha de apoio, e comunicados de "NÃO PUBLICAR" antes de uma manchete não são incomuns em portais na internet ${ }^{8}$. Como já apontado, porém, o contexto da publicação da agência de notícias indica a intenção de proteger o entrevistado. O porquê da iniciativa é um pouco mais complexo. Abordar a construção do relacionamento entre a mídia e o poder talvez ajude a esclarecer a questão.

Jürgen Habermas (2003) situa na aurora da Europa moderna a formação da "esfera pública", como espaço de discussão e legitimação da sociedade burguesa localizada entre os interesses privados e o Estado. A imprensa, então, se consolida como ferramenta a serviço deste espaço, até que pressões econômicas e a consequente emergência da publicidade desorganizam essa função.

De acordo com o modelo liberal de esfera pública, as instituições do público intelectualizado estavam [...] garantidas frente a ataques do poder público por estarem nas mãos de pessoas privadas. Na medida em que elas passam a se comercializar e a se concentrar no aspecto econômico, técnico e organizatório,

$7 \quad$ O uso de aspas busca indicar que se reconhece o poder de resistência do receptor diante das mensagens que recebe. $O$ termo, aqui, se refere à diferença de influência entre o indivíduo e o grande veículo de comunicação.

8 O Tumblr <http://jornalismovaicomdeus.tumblr.com/> é, inclusive, dedicado à compilação de tais situações.

Rev.Cad.Comun. Santa Maria, v.21, n.2, art 1, p.20 de 31, maio/ago.2017 
elas se cristalizam nos últimos cem anos, em complexos com grande poder social, de tal modo que exatamente a sua permanência nas mãos privadas é que ameaçou por várias vezes as funções críticas do jornalismo. (HABERMAS, 2003, p.220, 221).

Habermas prossegue demonstrando que, eventualmente, a linha entre notícia e anúncio desaparece em uma representação "jornalístico-publicitária" da esfera pública. Surgem então os "relações públicas", especializados na produção de novidades, repetição de determinados tópicos, entre outros mecanismos para uma "reorientação da opinião pública mediante a formação de novas autoridades ou símbolos que terão aceitação.” (2003, p. 227) ${ }^{9}$. O interesse geral, então, desaparece, substituído pela exposição de interesses particulares privilegiados dissimulados na esfera pública.

O autor tinha em mente a Alemanha pós-II Guerra Mundial na elaboração de sua tese. No Brasil, uma esfera pública, mesmo que altamente excludente, chegou a se formar durante o século XIX (PERLATTO, 2012), mas a imprensa já nascia com objetivos distorcidos. O primeiro jornal do país, ainda que publicado em Londres para fugir da censura imposta pela coroa portuguesa ${ }^{10}$, tinha um acordo de financiamento em troca de opiniões moderadas sobre o governo com Dom João VI. (BARMAN, 1994).

A prática prosseguiu de maneira geral e de forma mais ou menos explícita até ser institucionalizada pelo governo militar a partir de 1964, quando o presidente se tornou pessoalmente responsável pela concessão de novas licenças de rádio e televisão. (LIEDTKE, 2007). A evolução dos meios de massa no país, portanto, se deu por meio de uma relação personalista entre o governo e os amigos do poder, num cenário em que a imprensa já era utilizada como meio de defesa de interesses privados no espaço público.

A redemocratização, na prática, apenas passou a responsabilidade do

9 Hoje, pode-se dizer que as assessorias de imprensas promovem funções análogas aos "relações públicas" de Habermas. Essa ideia se torna especialmente sombria quando se percebe que as assessorias, em muitos casos, têm mais estrutura e capacidade do que as redações jornalísticas. O jornal El País, com base na comparação entre o número de funcionários da maior assessoria e do maior jornal do Brasil, especula que as assessorias de imprensa tenham mais que o dobro do tamanho das redações do país. Disponível em <http://goo.gl/c3Xlz6>.

10 Até 1808, a impressão e circulação de periódicos era proibida no Brasil.

Rev.Cad.Comun. Santa Maria, v.21, n.2, art 1, p.21 de 31, maio/ago.2017 
presidente para o legislativo ${ }^{11}$. Em 2002, ao ascender à presidência do país, Lula não fez modificações significativas à prática herdada. Por que, então, hoje há a percepção de que a mídia se coloca contra o governo? Percepção, aliás, corroborada por pesquisas da cobertura midiática dos partidos políticos. Uma delas, extraída do site Manchetômetro, mostra que o número de textos contrários ao Partido dos Trabalhadores (PT) nos jornais Folha de S. Paulo, O Globo e Estado de S. Paulo chegou a 116 em 12 semanas. No mesmo período, 15 reportagens criticavam o Partido do Movimento Democrático Brasileiro (PMDB), maior partido da base aliada do governo, e um número ainda menor abordava de forma negativa a oposição ${ }^{12}$. Quando se fala de textos de opinião, o abismo é ainda maior ${ }^{13}$.

É necessário, então, distinguir poder de governo. Ao menos em tese, a vitória do PT há 13 anos significou um rompimento com os setores conservadores da sociedade, detentores absolutos do poder econômico e, até então, político no Brasil. O grande veículo de comunicação é conservador por natureza, pois busca manter sua posição estabelecida na sociedade. Como agente político e econômico que é, acaba usando seu produto, a informação, para atingir tal objetivo. O comprometimento com essa posição e interesses de classes que historicamente lhe apoiam faz com que grandes veículos ultrapassem a função crítica e se consolidem como partido informal de oposição. (GUARESCHI, 2007).

Onde a Reuters, agência internacional, entra nessa equação, não é possível afirmar com tanta clareza. Poder-se-ia supor que, ao considerar "blindar" FHC, a agência pense nos interesses britânicos que clamam por uma política mais liberal em relação à economia do Brasil? O comunicado posterior da agência, com a explicação que se trataria de uma mensagem do editor para o repórter - que, por sinal, é coautor de uma autobiografia do ex-presidente ${ }^{14}$ - complica ainda mais a situação, colocando, talvez, elementos pessoais na história.

11 A Constituição de 1988 coloca diversas regras para a concessão de novas licenças de radio e televisão, como a proibição de que políticos sejam donos de emissoras, mas a maioria delas nunca saiu do papel.

12 Disponível em <http://www.manchetometro.com.br/cobertura-2015/cobertura-2015-partidos/>.

13 Ibid. Algumas exceções, como o Jornal do Brasil, inclusive exploram a distorção como assunto de seus próprios editoriais. Disponível em <http://goo.gl/TxH8Pv>.

14 O Improvável Presidente do Brasil - Recordações, lançado em 2006.

Rev.Cad.Comun. Santa Maria, v.21, n.2, art 1, p.22 de 31, maio/ago.2017 
Independentemente disso, o público percebeu a falha como uma tentativa de proteger interesses, e, em última instância, manipulação de informação. Hoje, uma simples busca no Google pelos termos "podemos tirar, se achar melhor" mostra que a frase virou sinônimo de mau jornalismo para um número considerável de internautas.

\section{A REPUBLICAÇÃo}

Muito mais impressionante que o erro da Reuters é sua republicação involuntária por outros veículos. Ao estamparem a frase inocentemente em suas páginas, os grandes portais revelaram uma faceta nada atraente do jornalismo brasileiro. Toda a credibilidade evocada por seus nomes cai por terra quando priorizam a necessidade de acompanhar o que entendem ser a dinâmica da internet.

Não há outra opção se não supor que ninguém, dentro da redação d'O Globo, Terra ou R7, leu o material oferecido pela Reuters. Visto que a manchete da reportagem abordava um assunto "em alta" e ainda favorecia o ponto de vista endossado pelos veículos, não deve ter havido dúvidas sobre a publicação. Uma análise mais aprofundada do material provocaria um atraso de preciosos minutos, tornando-a impraticável. Não há como deixar de evocar a crítica de Bourdieu (1997) quando pelo menos dez veículos republicam o mesmo material com tanta gana que ler seu conteúdo não é uma opção.

Para ser o primeiro a ver e a fazer alguma coisa, está-se disposto a quase tudo, e como se copia mutuamente visando deixar os outros para trás, a fazer antes dos outros, ou a fazer diferente dos outros, acaba-se por fazerem todos a mesma coisa, e a busca da exclusividade, que, em outros campos produz a originalidade, a singularidade, resulta aqui na uniformização e na banalização. (BOURDIEU, 1997, p. 27)

O autor francês se refere à logica televisiva, onde a preocupação com o índice de audiência se "retraduz na pressão da urgência" (p. 38). No entanto, dinâmica semelhante é verificada também na imprensa escrita, com intensidade variável por conta do próprio formato do meio - com preocupações de espaço/tempo diversas - e convicções de cada veículo.

Aqui, porém, essa lógica se impõe com força total. Bourdieu argumenta que a maioria do público não lê ou assiste a mais de um jornal, por isso

Rev.Cad.Comun. Santa Maria, v.21, n.2, art 1, p.23 de 31, maio/ago.2017 
a busca pelo "furo" seria apenas uma competição interna entre veículos. É possível que a facilidade de acesso a fontes diversas na internet tenha modificado essa realidade. Com certeza, ela acirrou ainda mais a crença sobre a importância da velocidade da informação para a imprensa. Paradoxalmente, num meio sem limitação técnica de tempo ou espaço.

É preciso ser o primeiro a publicar - a Reuters, afinal, não conta: como agência de notícias, seu alcance e objetivo não lhe torna concorrente direto dos portais jornalísticos. Se, em último caso, não for possível ser o primeiro a republicar o material, parte-se para a cópia do concorrente. Quem sabe ainda será possível roubar um pouco de sua audiência? O resultado, mais do que o atendimento imediato da sede de informações do público, é a uniformização total do conteúdo criticada pelo autor francês em uma escala antes inimaginável. Lê-se a mesma coisa - agora literalmente e com o mesmo erro - tanto no portal A quanto no B ou no $C$.

\section{O RECEPTOR-AUTOR}

A acidental exposição da frase "Podemos tirar, se achar melhor" e sua republicação são reflexos de práticas correntes nos grandes veículos de comunicação, transportadas para a internet. A relação entre público e veículo também é semelhante quantitativamente, na medida em que a audiência de canais de TV e jornais influencia a relevância de seus equivalentes online: rankings de acesso a sites indicam que as pessoas preferem os grandes portais para se informar, herança direta de sua experiência com os meios de massa ${ }^{15}$.

Neste ponto, Wolton (2010) é soberano: as tecnologias, por si só, não tem o poder de aperfeiçoar a comunicação. O que, então, a situação da Reuters apresenta de novo? Nada menos que um terço do processo ${ }^{16}$ : a reação do público. Ora, o francês é o primeiro a reconhecer a capacidade de resistência do receptor, que, para ele, sempre filtrou, hierarquizou e op-

15 Seis entre os dez sites informativos mais acessados no mundo são de propriedade de jornais ou emissoras de TV, apesar do portal Yahoo ocupar o primeiro lugar. No Brasil, dos dez sites mais acessados em todas as categorias, o Uol, proprietário da Folha de S. Paulo aparece em quinto, seguido pelo Globo.com e , somente então, o Yahoo. Disponível em <http://www.alexa.com/topsites/category/Top/News> e <http://www.alexa. com/topsites/countries/BR>.

16 Processo dividido simplificadamente em emissor - mensagem - receptor.

Rev.Cad.Comun. Santa Maria, v.21, n.2, art 1, p.24 de 31, maio/ago.2017 
tou por recusar ou aceitar as mensagens recebidas. Paradoxalmente, Wolton falha em perceber que a internet é o único meio que permite que essa resistência inerente diminua a assimetria entre os meios de comunicação e o indivíduo - grande preocupação dos teóricos críticos da comunicação no século XX. (MARTINO; FRANÇA; HOHLFELDT, 2007).

$O$ espectador dos meios tradicionais, ao se tornar testemunha de faIha, má-fé ou de algo que não concorde, está sozinho. No máximo, pode mobilizar seus conhecidos e, dependendo da gravidade do caso, talvez promover manifestações nas ruas. Mas ele não tem um meio à disposição para propagar sua mensagem - muito menos algo com a força de um canal de TV, periódico ou estação de rádio. Já na internet, mesmo partindo de uma situação desigual, o espectador pode, em alguns momentos, influenciar seus semelhantes a ponto de gerar um comportamento de massa e superar o grande veículo. É o que alguns autores chamam de "cascata". (KLEINBERG; EASLEY, 2010 apud RECUERO, 2012).

Em poucas horas, o caso "Podemos tirar, se achar melhor" virou assunto mais comentado nas redes sociais e serviu de pauta para outros sites - resposta imediata à demanda dos usuários, que provavelmente não seria atendida nos meios tradicionais, generalistas e centrados na oferta. A repercussão instantânea permitiu que a situação ganhasse tanta força que ofuscou o material original. É a materialização do "receptor-ator", termo cunhado pelo próprio Wolton (2010).

Mesmo assim, é fato que a situação ocorreu apenas por um descuido da agência de notícias. Ela tinha controle inicial da informação e, mesmo que involuntariamente, cedeu-o ao público. É preciso concordar que, em situações normais, "a extraordinária abertura de um espaço de informações interativas pela internet não altera fundamentalmente a relação bastante complicada dos indivíduos com a cadeia informação-poder-segredo-boato". (p. 35) $)^{17}$.

Uma evolução na relação entre o veículo emissor e o indivíduo receptor depende de mudanças mais amplas, mas o último parece pronto para trilhar novos caminhos. Exemplos recentes mostram situações radicalmente transformadas por pessoas comuns com acesso à internet e um celular com câmera. Em março deste ano, um menino de dez anos, morador

17 No entanto, Wolton afirma também que "as informações mais importantes do poder jamais são difundidas pela internet", afirmação que a emergência do Wikileaks, por exemplo, torna um tanto questionável.

Rev.Cad.Comun. Santa Maria, v.21, n.2, art 1, p.25 de 31, maio/ago.2017 
do Complexo do Alemão, favela do Rio de Janeiro, morreu com um tiro na cabeça. A primeira versão divulgada da tragédia indicava que a criança havia sido vítima de uma bala perdida. O relato, porém, foi logo desmentido pelos próprios moradores do local. Por meio de uma página no Facebook e chocante material em vídeo, eles provaram ${ }^{18}$ que o autor do disparo havia sido um policial'19.

Alguns dias depois, um jovem negro foi morto nos Estados Unidos durante confronto com a polícia. Ao menos, esse era o teor do material divulgado até uma testemunha que havia filmado a situação vir a público. O vídeo amador mostra o policial atirando nas costas do homem que corria desarmado ${ }^{20}$. Nos dois casos, os jornalistas acabaram, ao menos num primeiro momento, como reféns da versão policial. O público, contudo, desmontou a fonte oficial.

Barthes (1984), em seu A Câmara Clara, vislumbrou a essência da fotografia ao recordar-se de uma imagem que mostrava uma venda de escravos. "Meu horror e meu fascínio [...] provinham disso: era certo que isso existira: não se tratava de exatidão, mas de realidade: o historiador não era mais o mediador, a escravidão estava dada sem mediação, o fato estava estabelecido sem método". (p. 120)

Para o autor, o sentido final da imagem é a possibilidade da exposição absoluta de algo que, em última análise, fingido ou espontâneo, montado ou não, fatalmente ocorreu. Ao pegar emprestado esse pensamento,

18 "Provaram", talvez, seja o termo muito forte, já que as imagens não mostram o momento exato do disparo, e sim um policial deixando a cena sob gritos acusatórios de testemunhas.

19 Por seu teor, o vídeo foi removido do Facebook, mas se mantém em alguns portais, como o da Folha de S. Paulo - o que não deixa de provocar novas reflexões. Disponível em <http://goo.gl/87TUwH>. A página mantida por moradores do Complexo pode ser acessada em <https://www.facebook.com/complexoalemao2>.

20 Disponível em <http://brasil.elpais.com/brasil/2015/04/08/internacional/1428456835_130435.html>.

21 É necessário esclarecer que Barthes falava de uma realidade no sentido mais profundo possível, já que, em sua concepção, a foto "pode mentir quanto ao sentido da coisa, na medida em que por natureza é tendenciosa, jamais quanto a sua existência". (Ibid., p. 129)

Rev.Cad.Comun. Santa Maria, v.21, n.2, art 1, p.26 de 31, maio/ago.2017 
se quer dizer que na relação entre veículo de comunicação e espectador, somente na internet este pode ter a "certeza" da existência de um fato, quando, munida de um dispositivo de gravação - provavelmente um smartphone - e acesso à rede, uma testemunha indiferente à dinâmica jornalística registra e publica o que presenciou. Uma "verdade", então, pode vir à tona, não necessariamente única, mas concorrente a do veículo de comunicação. A credibilidade deste, sempre em conflito com seus interesses, de suas fontes e anunciantes, é contestada pelo registro cru, sem possibilidade de edição e alheia aos mecanismos de transformação do fato em notícia. Tal qual a foto de Barthes, é uma revelação absoluta, inocente. Em um cenário hipotético de popularização total da internet, a tecnologia dá ao antigo receptor o poder de eliminar o mediador da informação.

Contudo, deve ele ser eliminado? Wolton (2003) expõe sua posição com um exemplo simples, ao comentar a disponibilização do acervo da biblioteca do Congresso estadunidense na rede. "De que adianta acessar a biblioteca do Congresso se não se sabe o que buscar, se não se conhece os Estados Unidos, se não se tem nenhuma relação com esse universo, se não se sabe o que fazer com estas informações?” (p. 135). O mediador retorna, então, com força total. É ele que vai contextualizar a ação do receptor que também produz informação. Os assassinatos do menino brasileiro e do homem norte-americano, por exemplo, foram "retransformados" em notícia pelos veículos de comunicação para que uma discussão sobre o racismo fosse iniciada, com a participação de toda a sociedade. $\mathrm{O}$ mesmo se pode dizer da situação "Podemos tirar, se achar melhor", em que o "caos" provocado pelos usuários após revelação acidental da frase foi canalizado por outros portais que, somente então, forçaram uma resposta da Reuters.

\section{CONSIDERAÇÕES FINAIS}

Na relação com o grande veículo de comunicação, a internet fornece ao público autonomia inédita, mas a presença de uma estrutura especializada na produção e transmissão de informações continua indispensável. A complementaridade é clara. Livre para navegar no mar de informações disponível na rede, o internauta necessita do intermediário como filtro, guia e orientador. A grande revolução é a simples possibilidade, negada pelos meios tradicionais de massa, que o receptor tem de construir sua

Rev.Cad.Comun. Santa Maria, v.21, n.2, art 1, p.27 de 31, maio/ago.2017 
própria versão e seu próprio público, a partir de uma conjunção variada de fatores que ainda necessita ser melhor estudada.

Os caminhos que o indivíduo pode abrir com sua nova força só podem ser especulados. Com a popularização crescente da internet, ele está cada vez mais apto a fiscalizar e, quando necessário, atuar como contraponto à grande imprensa - função extremamente necessária num país como o Brasil, onde ela é altamente concentrada. Ao mesmo tempo, não se pode afirmar se, por si só, o acesso levará à pluralização de ideias, sem o apoio de políticas públicas ou de setores organizados da sociedade. $O$ equilíbrio de forças entre público e veículo ainda engatinha e necessita se fortalecer para que a comunicação possa ser resgatada da esfera puramente econômica em que se encontra e passe a ser tratada como um direito básico do indivíduo.

Durante esse processo, é mais do que nunca necessário escapar do deslumbramento tecnológico denunciado por Wolton. Conforme aumenta a audiência da internet, há de se fortalecer a lembrança de que ela não é um canal de comunicação direta, apesar das aparências. Embora ocultos, os intermediários detentores da tecnologia ganham força. Em especial, os gigantes Google e Facebook, que - informação frequentemente relegada a segundo plano - são empresas, sustentadas predominantemente pela publicidade, com seus interesses econômicos, políticos e uma terrível particularidade: o poder cada vez mais absoluto de controlar quem vê o quê. Se a tendência se confirmar e a força da internet se equiparar à dos tradicionais meios de massa, essa deve ser, sem dúvida, a principal reflexão dos estudiosos e usuários da rede. 


\section{REFERÊNCIAS}

ALEXA. Actionable Analytics for the Web. Disponível em: <http://www.alexa.com/>. Acesso em: 3 maio 2015.

BARMAN, Roderick. Brazil: The Forging of a Nation, 1798-1852. California: Stanford, 1994.

BOURDIEU, Pierre. Sobre a televisão. Rio de Janeiro: J. Zahar, 1997.

CARTA CAPITAL. "Podemos tirar, se achar melhor". 24 mar. 2015. Política. Disponível em: <http://www.cartacapital.com.br/blogs/midiatico/podemos-tirar-se-achar-melhor-podemos-2154.html>. Acesso em: 3 maio 2015.

COMPLEXO ALEM O. Disponível em: <https://www.facebook.com/complexoalemao2>. Acesso em: 3 maio 2015.

FERES JÚNIOR, João (Coord.). Manchetômetro. Disponível em: <http://www.manchetometro.com.br/>. Acesso em: 8 maio 2015.

FOLHA DE S. PAULO. Menino de 10 anos é quarta vítima no Complexo do Alemão em 24 horas, Rio de Janeiro, 2 abr. 2015. Cotidiano. Disponível em: <http://www1.folha.uol. com.br/cotidiano/2015/04/1611963-menino-de-10-anos-e-quarta-vitima-no-complexo-do-alemao-em-24-horas.shtml>. Acesso em: 3 maio 2015.

GUARESCHI, Pedrinho Arcides. Mídia e democracia: o quarto versus o quinto poder. Debates, Porto Alegre, v. 1, n. 1, p.6-25, jul./dez. 2007. Trimestral. Disponível em: <http://www.seer.ufrgs.br/index.php/debates/article/view/2505/1286>. Acesso em: 3 maio 2015.

HABERMAS, Jürgen. Mudança estrutural da esfera pública: investigações quanto a uma categoria da sociedade burguesa. 2.ed. Rio de Janeiro: Tempo Brasileiro, 2003.

JORNAL DO BRASIL. Para blindar FHC, 'Reuters' propõe em matéria: 'podemos tirar se achar melhor’. 24 mar. 2015. País. Disponível em: <http://www.jb.com.br/pais/noticias/2015/03/24/para-blindar-fhc-reuters-propoe-em-materia-podemos-tirar-se-achar-melhor/s Acesso em: 3 maio 2015.

JORNAL DO BRASIL. O que há por trás das tentativas de desestabilizar Dilma Rousseff. 30 mar. 2015. Opinião. Disponível em: <http://www.jb.com.br/opiniao/noticias/2015/03/30/o-que-ha-por-tras-das-tentativas-de-desestabilizar-dilma-rousseff/> Acesso em: 5 maio 2015.

JORNALISMO VAI COM DEUS. Disponível em: <http://jornalismovaicomdeus.tumblr. com/>. Acesso em: 10 maio 2015.

LIEDTKE, Paulo Fernando. O movimento pela democratização da comunicação no Brasil: os embates entre o Estado, as empresas de mídia e a sociedade civil. In: SEMINARIO NACIONAL MOVIMENTOS SOCIAIS, PARTICIPACÃO E DEMOCRACIA, 2., 2007, Florianópolis. Anais... . Florianópolis: UFSC, 2007. p. 434 - 466. Disponível em: <https:// xa.yimg.com/kq/groups/28011239/1331987661/name/paulo_liedtke.pdf >. Acesso em: 3 maio 2015.

Rev.Cad.Comun. Santa Maria, v.21, n.2, art 1, p.29 de 31, maio/ago.2017 
MARTINO, Luiz Claudio; FRANCCA, Vera Veiga; HOHLFELDT, Antônio (Org.).Teorias da comunicação: conceitos, escolas e tendências. 7.ed. Petrópolis, RJ: Vozes, 2007.

MONGE, Yolanda. Mais um policial mata um homem negro desarmado a tiros nos EUA. El País, Washington, 8 abr. 2015. Internacional. Disponível em: <http://brasil.elpais. com/brasil/2015/04/08/internacional/1428456835_130435.html>. Acesso em: 3 maio 2015 .

ORRICO, Alexandre. Agência sugere omitir menção ao PSDB no escândalo da Petrobras. Buzzfeed, 24 mar. 2015. Disponível em: <http://www.buzzfeed.com/alexandreorrico/agencia-sugere-omitir-mencao-ao-psdb-no-escandalo-da-petrobr\#.ujDvevgeX> Acesso em: 3 maio 2015.

PERLATTO, Fernando. Habermas, a esfera pública e o Brasil. Estudos Políticos, Rio de Janeiro, v. 4, p.78-94, jan./jun. 2012. Semestral. Disponível em: <http://revistaestudospoliticos.com/wp-content/uploads/2012/04/4p78-94.pdf>. Acesso em: 5 maio 2015.

RECUERO, Raquel. A rede é a mensagem: Efeitos da Difusão de Informações nos Sites de Rede Social. In: VIZER, Eduardo (Org.). Lo que Mcluhan no previó. Buenos Aires: La Crujía, 2012. p. 205-223. Disponível em: <http://www.raquelrecuero.com/arquivos/redemensagem.pdf>. Acesso em: 8 maio 2015.

ROSSI, Marina. A versão mais forte? EI País, São Paulo, 1 jan. 2014. Sociedade. Disponível em: <http://brasil.elpais.com/brasil/2014/01/25/sociedad/1390678371_750307.html>. Acesso em: 10 maio 2015.

WINTER, Brian. ENTREVISTA-FHC diz que Lula tem mais responsabilidade política em caso Petrobras do que Dilma. Reuters, 23 mar. 2015. Brasil. Disponível em: <http:// br.reuters.com/article/domesticNews/idBRKBNoMJ2B120150323>. Acesso em: 3 maio 2015.

WOLTON, Dominique. Internet, e depois? Uma teoria crítica das novas mídias. Porto Alegre: Sulina, 2003.

WOLTON, Dominique. Informar não é comunicar. Porto Alegre: Sulina, 2010. 


\section{Ana Maria Acker}

Doutoranda em Comunicação e Informação na Universidade Federal do Rio Grande do Sul (UFRGS) e mestre pela mesma instituição. Professora do curso de Jornalismo da Universidade Luterana do Brasil (Ulbra).

E-mail:ana_acker@yahoo.com.br

\section{Lucas Demeda dos Santos}

Estudante dos cursos de Bacharelado em Comunicação Social - Jornalismo e Bacharelado Ciências Econômicas da Universidade de Caxias do Sul (UCS) e bolsista do Observatório do Trabalho da mesma instituição, atualmente em intercâmbio na Universidad Diego Portales (Santiago, Chile). E-mail: lucasdemeda@gmail.com

RECEBIDO EM: 03/08/2016

ACEITO EM: 03/10/2016 